La fluorescence en biochimie

Par Prof. Ch. Dhéré. (Les problèmes biologiques, 21.) Pp. $x i i+318+27$ plates. (Paris : Les Presses universitaires de France, 1937.) 80 francs.

$\mathrm{T}$ some respects this treatise may be regarded as a counterpart of the same author's contribution to Abderhalden's "Handbuch der biologischen Arbeitsmethoden" reviewed in Nature in 1935. However, it is by no means a translation, for the arrangement is different, and much of the matter has been brought well up to date; indeed, the author (p. xi) distinguishes ketween the two works.

The treatment is concise and eminently practical throughout, and anticipates possible experimental difficulties on the part of the inquirer ; for example, on p. 233, the author, speaking of hæmatoporphyrine in pyridine, leads the reader from the first impression that there is only one fluorescent band to the discovery that there are really two. Apparatus is described in detail. The main themes of practical interest to the biologist are dealt with in separate chapters, where each receives such comprehensive treatment that few readers will fail to gain either the information or the guidance they need ; for example, those on glucides, fats, proteins, alkaloids, chlorophylls, bile pigments, vitamins, microbes, each with its own bibliography; these occupy 250 pages. The present reviewer does not recall the toluene experiments attributed to him (p. 69); his own more recent work, as yet unpublished, makes him critical of any observations on the fluorescence of the sugars, including his own earlier work, unless the material has been rigorously purified; hence the data on pp. 65-68 should be read with discrimination.

The book is not burdened with much theory, but it discusses at some length spectroscopic aspects of the subject. It is furnished with fifty-two figures in the text, and a further fifty-six, mainly spectrograms, in twenty-seven plates. The book as a whole is well produced.

S. JUDD LEwIS.

A Systematic Review of the Genus Phylloscopus (Willow-Warblers or Leaf-Warblers)

By Claud B. Ticehurst. Pp. viii $+193+2$ plates. (London: British Museum (Natural History), 1938.) $10 s$.

R. TICEHURST has for long been recognized as an authority on the willow-warblers, and this critical revision of that group is a model of what such a work should be. $\mathrm{He}$ has based it primarily on his own examination of thousands of specimens available in museum collections, and only secondarily on the previous literature. By his determination, there are thirty species in the genus and these comprise, in all, sixty-seven separable forms. They are distributed across Europe and Asia, the largest number of forms being found in the mountain ranges bordering the Tibetan plateau: two are strangely isolated on the islands of Flores and Timor.

Of the three which breed in the British Isles, the ordinary willow-wren and the chiffchaff are scarcely distinguishable by sight under ordinary field conditions, although their songs are strikingly different, and this is indicative of the difficulty of the group as a whole. The complexity is increased by the fact that allied species show parallel variations in corresponding parts of the area which they jointly inhabit; but this is itself one of the points of general biological interest which emerge in the present study.

Most of the forms are migratory, and although information as to winter ranges is in many cases still far from complete, the general trends are becoming clearer. One form which breeds only in north-eastern Siberia winters in Africa, and one with a breeding range extending as far west as northern Norway does not winter nearer there than Siam : these two movements, the greatest exhibited in the group, cross each other at right angles.

The book includes useful sketch maps illustrating distribution and migration; the two coloured plates by Mr. Roland Green show eleven species of which no plate had hitherto been published.

\section{Index Kewensis Plantarum Phanerogamarum}

Supplemeritum 9: Nomina et Synonyma omnium Generum et Specierum ab initio anni 1931 usque ad finem anni 1935 nonnulla etiam antea edita complectens. Ductu et consilio A. W. Hill. Confecerunt Herbarii Horti Regii Botanici Kewensis Curatores. Pp. iii +305. (Oxford: Clarendon Press; London : Oxford University Press, 1938.) 84s. net.

$O^{N}$ NLY five years have elapsed since the publication of Supplement 8 to the "Index Kewensis" and in Supplement 9 botanists are presented with a volume considerably larger than any of its immediate predecessors. Since the first appearance of the "Index" in 1893-made possible by the munificence of Charles Darwin-the publication of each Supple. ment marks a stage in the progress of systematic botany, and provides the only authoritative list of the names of plants recently described, the author and place of publication of each, together with an indication of the geographical distribution. Of the many important works which emanate from Kew none is so indispensable to botanists in general and to systematists in particular.

The present work is essentially what it sets out to be-an index, and its general plan follows that of earlier Supplements. The size of the volume is some indication of the large amount of work which has been accomplished in the systematic study of Phanerogams during the years indicated on the title page. The new genera which have been described are shared among numerous families, but reference may be made to the considerable number of additions to Compositæ, Gramineæ and Orchidaceæ, while students of so-called critical genera such as Capsella, Rubus, Hieracium and Taraxacum will find a large number of new specific names for their consideration.

In the preparation of a work of this kind it is unlikely that omissions will not occur, and in the present Supplement a number of entries refer to species which were described before 1931. There can be nothing but praise, however, for those members of the staff at Kew who have undertaken the compilation of the work and for the great care they have bestowed upon its preparation. The volume is sure of a warm welcome from botanists and horticulturists throughout the world.
J. R. M. 